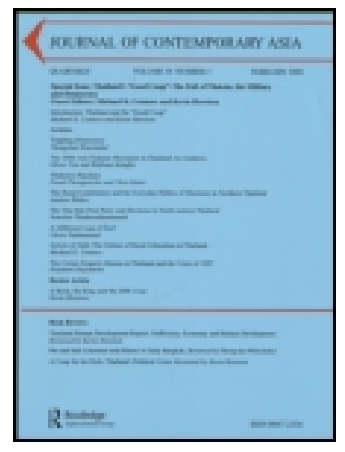

Journal of Contemporary Asia

\title{
The US and the Asian Development Bank: Origins, structure and lending operations
}

\section{Nitish Dutt}

To cite this article: Nitish Dutt (2001) The US and the Asian Development Bank: Origins, structure and lending operations, Journal of Contemporary Asia, 31:2, 241-261, DOI: 10.1080/00472330180000141

To link to this article: http://dx.doi.org/10.1080/00472330180000141

曲 Published online: 14 May 2007.

5 Submit your article to this journal

Џlll Article views: 193

Q View related articles $₫$

4 Citing articles: 8 View citing articles 


\title{
The US and the Asian Development Bank: Origins, Structure and Lending Operations
}

\author{
Nitish Dutt*
}

\begin{abstract}
[Abstract: The dominant discourse related to the establishment of the Asian Development Bank revolves around its structure, functions and lending operation. But the self-serving role played by the US during its formative years has been largely neglected. This article focuses on the early years of the Bank (1967-1972) and American efforts to make it a subservient tool of American foreign policy. A close examination of American role and influence within the Bank during its formative stage illustrates how multilateral institutions, funded by rich countries, can be used to force poor nations adopt methods for dealing with their problems, at odds with their own interest.]
\end{abstract}

The idea of regional cooperation for mutually advantageous economic development has attracted growing attention since the end of WW II. The United States too had from time to time shown an interest in the idea but never pursued it actively. Starting in the mid sixties however, the US began to take an active interest and in fact was instrumental in the formation of the Asian Development Bank and shaping its structure and functions. What accounts for this sudden shift in US willingness to get involved in the Bank "ground up?" This article explores why the US played a leading role in the formation of the Bank and how it shaped its structure and functions to subserve its own political and economic interests.

While dominant discourse related to the ADB in general, its economic program, structure and lending operations, ${ }^{\prime}$ little or no attention has been paid to examining the extent to which the Bank is a reflection of the priorities and concerns of its founding members, especially the US. Thus, the existing narratives related to the formation of the Bank tends to overlook or ignore the self-serving role played by the United States during the banks formative years. The paucity of secondary sources on the subject is reflective of this fact. A close examination of the role played by the US during its formative stages, helps to highlight the manner in which multilateral institutions, funded by rich countries, can be used to force poor countries to adopt methods for dealing with their problems at odds with their own interest. The parallels with the US role in shaping and controlling international agencies like the International Monetary Fund and the World Bank and their use as tools of American foreign policy, are quite striking.

* Dept. of Political Science and Public Administration, Bitkent University, Ankara, Turkey Journal of Contemporary Asia, Vol. 3I No. 2 (200I) 
For this purpose of illustrating America's role in the formation and shaping of the Bank's identity and role, this article focuses on the years between 1965 and 1972. From the perspective of this article this period is important for a number of reasons. First, it was during this time that the United States was most active in guiding the activities of the Bank. First, American involvement in the formation and shaping of the Bank was most pronounced as the Johnson administration saw multilateralism as a way to influence the policies of member countries, without raising the kind of questions related to the use of bilateral means. Second, the extent to which a supposedly autonomous, multilateral institution can be reduced to the status of a policy instrument in the hands of the most powerful countries within the Bank, is most clearly illustrated by the American role during this period and lending activities of the fledgling Bank under pressure from the US and Japan. As the evidence presented in this paper suggests, the manner in which the US used its influence during the early years of the Bank was a source of concern and resentment among its more independent minded members. Despite this fact, American pressure, along with the cooperation of Japan and some developed countries was instrumental in overcoming these objections.

\section{The US and the Formation of the ADB}

Suggestions for establishing a regional development bank in Asia, date back to as early as 1954. At that time the member countries of the Economic Commission for Asia and the Far East (ECAFE) and its secretariat began talking about the formation of an Asian development bank. Unfortunately the idea aroused little enthusiasm among the member countries, and the United States and Japan in particular, were actually opposed to it, as they saw drawbacks to such an institution. The United States "was reluctant to adopt a multilateral approach [to development aid] that would limit American influence," while Japan did not want to lend its resources to an institution "that seemed destined, like the World Bank to become primarily an instrument of American policy.",

Discussion of the possibility of establishing the Bank was reactivated in August 1963, again under the auspices of ECAFE. The initial impetus for forming the Bank and the proposal to do so emanated not from direct discussions among sovereign states, but within the framework of the ECAFE secretariat. It was U Nyun, ECAFE's executive secretary, rather than the Asian states (as Watanabe claimed ${ }^{4}$ ) who then took the initiative in encouraging and channeling these discussions into concrete proposals.

The discussion leading to the creation of the Bank moved quickly. In all it took two years from the first formal proposal to the signing of the agreement establishing the Bank. Generally speaking this period can be divided into two broad phases. From August 1963 to April 1965, the initiative and the enthusiasm came almost exclusively from U Nyun and the ECAFE secretariat. From April 1965, up to the signing of the 
agreement and beyond, additional and perhaps crucial momentum was provided by the United States in the person of Eugene Black, former President of the International Bank for Reconstruction and Development (popularly known as the World Bank), who embarked on a fund raising tour of Europe. In his effort to secure the financial backing of the developed European countries for the proposed Bank, Black was eminently successful as witnessed by the large number of European countries which subsequently became members of the institution.

His efforts were not confined to winning support for the Bank. He also played a central role in shaping and formulating the structure and functions of the Bank. From the United States point of view it was felt to be more important for the Bank to qualify as a solvent financial institution, than the Bank to have a clearly "Asian" character. Probably for this reason Eugene Black took a personal interest in the selection of the Bank's first president, Takeshi Watanabe," a person who was considered to be "primarily responsible for Japan's success on the world capital market." With regard to giving the Bank an Asian character, the position of Japan as an Asian, yet developed country was bound to be crucial. However, Japan was initially reluctant to commit itself "lest it should find itself bearing a disproportionate financial burden" in an institution, which it felt seemed destined to become a tool of American policy.

Formal discussion of the possibility of setting up an Asian development bank began in August 1963, under the auspices of ECAFE. This was the result of a resolution passed at the nineteenth session of ECAFE, early in 1963, calling for accelerated measures of regional economic cooperation The result was a proposal put forward by an expert group formed by U Nyun to establish an Asian bank. This proposal was endorsed by the ministerial conference held in Manila in December 1963, which directed that further studies should be undertaken.

As a result another Ad hoc Working Group of Experts on the Bank was established by U Nyun under the chairmanship of Mr. M. Uquali, managing director of the Pakistan Industrial Credit and Investment Corporation. The group's report showed a sharp change of tone. The strategic view of the Bank as one of a broad range of instruments for changing the internal structure of the region gave way to a narrower, more institutional view in which the emphasis was on the functions, resources, and structures of the Bank itself. This change in outlook regarding the Bank can only be explained by the fact that the Expert Group consisted mainly of bankers so that their approach reflected their own professional inclinations.

Under the terms of the original proposal the Bank had been conceived as an instrument for promoting regional economic cooperation among its Asian members, besides furthering economic development. Yet, from the report of the Ad Hoc Group of Experts, it became clear that this important function was not only listed third in the order of priorities, but was also given little attention. Understandably, therefore the report 
was primarily concerned with the Bank's capital structure, subscriptions, voting and so on. In this connection, it is noteworthy that inspite of its concern for attracting additional capital resources to the region, it gave virtually no consideration to the question of establishing a special fund for lending at low interest rates or soft terms. It was Mr. Black on behalf of the United States, who in his words found himself "in the unaccustomed position of urging my Asian friends not to rely too heavily on conventional instruments of finance." The question that comes to mind in this connection is why was the United States so interested in establishing a soft fund when the would-be beneficiaries themselves were not too keen, in the interest of seeing "their" bank qualify as a sound financial institution? The answer to the question is to be found in the nature of the Special Fund. As conceived by the United States and Japan, the loans made out of this fund would be tied to the purchase of goods and services from the donor countries. It was this aspect of the proposed soft loans which was possibly the main reason (though never openly expressed, except by Cambodia) ${ }^{12}$ for the Asian regional countries being unenthusiastic about establishing a Special Fund. Their subsequent interest in such a fund would seem to be indicative of the success of Black in calming the fears regarding the possibility that a tied Special Fund - as proposed by the United States and Japan could compromise the sovereignty and independence of these countries.

Unlike the Ordinary Funds, ${ }^{13}$ the Special Fund was meant to finance the purchase of goods and services from the donor countries. Thus, whatever the amount of the United State's contribution to the Bank's Special Funds might be, the market for American goods and services would be enhanced to that extent. This point was repeatedly emphasised by Joseph W. Barr, Under-Secretary of the Treasury, during the hearing on the Asian Development Bank Act and the Special Fund before the Committee on Foreign Relations. In his statement before the Committee on February 16, 1966, Barr emphasised that "any U.S. contributions as special funds to the Bank can be tied explicitly to procurement in the United States."

Guided by the Working Group's ideas and recommendations the ECAFE secretariat prepared a draft charter. ${ }^{15}$ The model that took shape was similar to the World Bank in character. What emerged was a straightforward financial institution, in which the developed countries would be dominant, and the chief purpose of which would be the financing of economic projects from its Ordinary Funds, selected on the basis of comparative rates of return on each loan. In other words financially profitable, quick return projects were to be given priority over projects which promised greater economic and social benefits in the long run to the recipient countries but slower and lower rates of return.

This model was then presented to the twenty-first session of ECAFE, held in Wellington, New Zealand, in March 1965. According to the summary records, the representatives of Britain, France, and the United States made no mention of the Asian 
Bank in their contributions to the discussions. ${ }^{16}$ The silence on the part of the United States was indicative of its lack of interest, since this meeting took place prior to the shift in United States policy towards greater support for regional institutions in Southeast Asia. This position was to be dramatically reversed a month later. Also significant was the position taken by Japan, which, while expressing interest in principle, was of the opinion that "the cooperation and participation of the developed countries outside the region were essential." ${ }^{17}$ Roughly translated, this meant that Japan was waiting to see whether or not the Americans would join the Bank.

It was clear that further persuasion of the developed countries and in particular the United States would be needed in order to get the Bank launched. The participants to the conference therefore adopted a resolution ${ }^{18}$ establishing a consultative committee, one of the principal functions of which was to undertake consultations with the governments of the developed countries outside the region regarding their interest in and the extent of their likely participation in the Asian Development Bank. The countries represented on the committee were Ceylon, India, Iran, Japan, ${ }^{19}$ Malaysia, Pakistan, the Philippines, the Republic of Vietnam, and Thailand.

The scheme gained momentum in April 1965, when the United States for the first time manifested real interest in the institution. The reason for this sudden enthusiasm was apparently the war in Vietnam. The American commitment and casualties in the country were growing with alarming speed. Already, some 400 Americans had died there. Vietnam was fast developing into a trap from which it would be increasingly difficult to extricate the United States.

Financial backing for the $\mathrm{ADB}$ and other regional organizations in similar situations was probably seen as a way by which the United States, in cooperation with other developed countries, could help (at less cost to itself) the vulnerable nations of Asia to be more self-reliant economically and militarily, thereby strengthening their capacity to defend themselves against what it perceived to be the ever present communist threat. In addition, the United States by taking an active interest in the economic development of Asia could demonstrate to the world in general, and its Southeast Asian allies in particular, that its concern for the economic welfare of these countries extended beyond its immediate political and security preoccupations. It was possibly because of these reasons that President Johnson in a speech delivered at John Hopkins University in April 1965, declared that the United States was prepared to help regional self-help programmes with a one billion dollar American investment. ${ }^{20}$ To implement this programme, he appointed Eugene Black as his special adviser on Southeast Asia. Black was instructed to contact Secretary General U Thant immediately to ask him what concrete steps the United States could take then and there to signal its interest in regional cooperation.

American support for the proposed Bank now rapidly evolved into sponsorship. In July, the consultative committee visited 34 countries, including fourteen outside the 
Asian region, one of which was the Soviet Union. Simultaneously, Black embarked on a fund-raising tour of Europe. Washington's backing for the proposed Bank considerably improved the financial prospects of the institution and made it more acceptable to the developed Western countries as a whole. One indication of this was the decision of Switzerland, which had consistently refused to join the Bank, to become a full member, with a $\$ 5$ million subscription.

On the completion of its tour of potential member countries, the committee again reassembled in Bangkok in August for final discussions and to prepare a draft charter for the Bank. At a preparatory meeting of officials from 31 countries held in October, this draft charter was adopted with certain amendments. These amendments were primarily designed to clarify certain technical details. The only substantive matter to be dealt with in any detail by the Committee was related to the question of balance of control between the regional and non-regional members. It was decided that voting should be related to subscription, with only a small redress in favour of the smaller members through the allocation of $20 \%$ of the votes, which were to be divided equally among all the members of the Bank regardless of the level of their subscription. To make this arrangement more acceptable to regional members like Japan, Australia, New Zealand and the less developed Asian countries, it was decided that these countries should always have a majority of the voting power. This was meant to assure the "Asian" character of the institution.

The delegation from the Soviet Union was the only one to point out the weakness of this assurance, arguing that the significant feature of the proposed voting power was that the developing countries "would always be in a minority." clear that the Soviet Union was not going to become a member. It is interesting and somewhat intriguing to note that Mr. Black, who was present at the meeting, subsequently stated in reply to a question from Senator Aiken (during the course of the hearing on the ADB Act) as to why the Soviet Union declined to join the Bank: "I don't remember what the reasons were or if I did hear I didn't understand them"! ${ }^{24}$ Black's answer represented an attempt to evade a question, a direct answer to which could have led to a number of more awkward queries, as regards the United States' role in assuring the dominance of the developed countries within the Bank.

The Bangkok meeting was followed by one in Manila where the Consultative Committee prepared a final report. This was presented to a conference of Asian ministers which took place in Manila immediately afterwards. The conference accepted the draft charter, but got entangled in the question of location of the Bank's headquarters. ${ }^{25}$ After considerable discussion and lobbying, Manila was selected, much to the disappointment of the other members, especially Iran and Japan. As a matter of fact, Iran, offended by the rejection of its offer to house the Bank, subsequently withdrew from membership. 
Following the adoption of the draft text by the Asian ministers, the agreement was signed in Manila at a Conference of Plenipotentiaries of thirty one countries that followed immediately after the Ministerial Conference. The agreement was then left open for further signatures until 31 January 1966, in Bangkok. It entered into force on 22 August 1966, when in accordance with the charter it had been ratified or accepted by fifteen signatories, including at least ten countries in the ECAFE region, whose initial subscription in the aggregate comprised not less than sixty-five per cent of the authorised capital stock of the Bank. The inaugural meeting was held in Tokyo in November, and was attended by thirty-one countries.

The speed with which the discussions moved after the appearance of Black on the scene suggests that the most conspicuous accelerating force was the sudden interest of the United States. Part of the explanation is to be found in the desire of the United States to "become active at... [the] very beginning," so as to increase its "own constructive influence in the organisation and management of the Bank." ${ }^{28}$ However, this does not constitute a sufficient explanation of the speed with which the preparatory discussions were completed. A more satisfactory explanation is to be found in the success of the developed states in foisting a prefabricated institutional formula, which was not in any sense derived from the needs of the Asian nations, upon the prospective members.

Furthermore, the importance of the American role in speeding up the process of establishing the Bank seems to be reinforced by the fact that it was the backing of the United States which ensured the approval of other Western nations for the Bank. Equally significant was the presence of Eugene Black coupled with the election of Mr. Watanabe, and the general awareness among financial specialists that rates of return on investment in Asia are exceptionally high, ${ }^{29}$ ensured the confidence of international financial institutions. This confidence was expressed at the inaugural meeting in Tokyo, in November 1966 , by the presence of the representatives of some sixty commercial banks and other financial corporations, including more than twenty each from the United States and Japan, and eight from Britain.

The strong dependence of the developing countries on the United States, both for its financial contributions and for securing donations of capital from other developed Western countries, gave it a big voice in the shaping of the Bank along lines favourable to the pursuit of its own political and economic interests. This dependence meant that the developing regional members, even though they had some reservations, especially with regard to the distribution of voting power within the Bank, were compelled to go along with the position taken by the developed countries. It was a case of beggars can never be choosers.

The professed objective of the Bank, as laid out in the Articles of Agreement, is to "foster economic growth and co-operation" in the Asian region and to accelerate the "process of economic development of the developing member countries in the region 
collectively and individually." Hence, economic development is explicitly equated with economic growth, suggesting a purely quantitative approach devoid of any qualitative aspects like "social progress." This latter concepı was dropped, and was replaced by the looser term "cooperation," which had emerged in the sixties as a catchword for the comfort of small and vulnerable developing countries, anxious to construct larger political and economic units. The assumption was that such units in some sense would be more viable. For developed countries "viable" meant "not needing aid." For developing countries, it meant among other things being in a stronger bargaining position to get more aid.

In keeping with its purpose, the Bank is required to give priority to projects and programmes which would effectively promote "harmonious economic growth of the region as a whole." At the same time, it is required to give special consideration to the needs of the smaller nations. The Bank's functions also include the promotion of public and private investment, the provision of assistance in the coordination of national policies, particularly in foreign trade, and the provision of technical assistance in the preparation of projects.

The financial resources of the Bank consist of the authorised capital stock, funds raised by borrowings, funds received in repayment and income derived from loans and guarantees, and any other funds received which do not constitute "Special Funds." From its ordinary resources, the Bank may set aside $10 \%$ of its paid-in capital for the purpose of establishing Special Funds. It may also accept resources for administration as Special Funds, provided that these funds are designed to serve the purpose and come within the functions of the Bank. Special Funds derived from the Bank's own resources are to be used for lending on more generous terms than those established by the Bank for its ordinary operations. Special Funds received from other sources may be used in any manner that is consistent with the Bank's functions, subject to an implicit reservation concerning such conditions as may be attached to their use by the country or institution which provides them. Theoretically speaking, the Bank would seem to have had a lot of leeway in the administration of the Special Fund, but in actual practice the position was quite different.

Within the Bank, those who had given most thought to the question of Special Funds were the executive directors representing the developed countries. If this at first seems odd, it becomes more readily explainable in the context of the political and economic objectives of the larger donors within the Bank, especially the United States and Japan. While the charter empowers the Bank, under the supervision of its Board of Directors, to administer the funds and make the detailed programme judgments involved, it can do so only with the expressed consent of the Governors of the countries contributing to the Special Funds. For example, the Special Report of the National Advisory Council on Special Funds of September 1967 stated that: 
the main channel through which the United States would exercise its influence in shaping Bank decisions regarding special funds would be the U.S. representation on the Bank's Board of Governors and the Board of Directors, in which the principle of weighted voting applies. ${ }^{33}$

This arrangement, then, permits the United States "to make stipulations regarding the use of... funds when given...."

The Bank is open to membership by members and associate members of the United Nations ECAFE and by other regional and non-regional countries which are members of "the United Nations or any of its specialised agencies. Thus, the Chinese Peoples' Republic (at the time of the Bank's formation), Democratic Peoples Republic of Korea, and Democratic Republic of Vietnam were not eligible for membership. It was originally hoped that the Soviet Union would join, and this hope was shared by the United States. ${ }^{36}$ However, the Soviet Union along with the East European countries refused to join, on the grounds that it objected to the proposed distribution of voting power between the developed countries and the developing countries. For the same reason, France also refused to join in the beginning.

The absence of any Communist country in the ADB led Henry S. Bloch, one of those most closely associated with its creation, to regard the institution as having a frankly "Western" image. Apparently for this reason, Burma and Outer Mongolia refused invitations to join. For similar reasons Indonesia did not apply for membership until the fall of Sukarno in 1966 who during the later years of his rule, considered the United Nations and other organisations of which the United States was a member, as tools of "neo-colonialism.", Cambodia accepted membership, but with some qualms, which were clearly expressed at the inaugural meeting of the Bank. Mr. Son Sann, Governor for Cambodia, observed:

... we cannot ignore the fact that many Asian countries remain outside this organisation. In our opinion, their absence should not be ascribed to any deliberate desire to neglect, or to show indifference towards, the best interests of this part of the world. But it is perhaps due rather to misgivings lest the Bank should neglect the objectives set out in its statutes ... and should engage in other activities of a more or less political nature.

From this point of view, Cambodia's decision to become a member of the Asian Development Bank is attended with a certain amount of risk. With this consideration in mind, Cambodia.. asks... that it should be treated fairly without recourse to occult pressures or discriminatory practices."

Cambodia subsequently announced its withdrawal from membership, but later retracted its withdrawal.

Admission of new members requires an affirmative vote of two-thirds of the total number of governors, representing not less than $75 \%$ of the total voting power. This means that neither the United States nor Japan by itself has a veto, but combined the two countries, with $34.24 \%$ of the voting strength (see Table 1.1 ), can prevent any new member from being admitted, if they choose to do so. In any case, even if they did not act in concert, it is unlikely that any new member could be admitted against opposition from either Japan or the United States. 
Table 1: Loans - Approvals and Commitments as of 31 December 1972

\begin{tabular}{lccc}
\hline Country & $\begin{array}{c}\text { Ordinary } \\
\text { Capital }\end{array}$ & $\begin{array}{c}\text { Special } \\
\text { Funds }\end{array}$ & $\begin{array}{c}\text { Ordinary Capital + } \\
\text { Special Funds }\end{array}$ \\
\hline Afganistan & - & 5.15 & 5.15 \\
Republic of China & 99.99 & - & 99.99 \\
Fiji & 4.70 & - & 4.70 \\
Hongkong & 21.50 & - & 21.50 \\
Indonesia & - & 69.64 & 69.64 \\
Khmer Republic & - & 1.67 & 1.67 \\
Republic of Korea & 196.80 & 3.70 & 200.50 \\
Laos & - & 4.34 & 4.34 \\
Malaysia & 76.60 & 3.30 & 82.90 \\
Nepal & 2.00 & 35.71 & 35.71 \\
Pakistan & 67.15 & 18.20 & 85.35 \\
Papua New Guinea & - & 14.60 & 14.60 \\
Philippines & 101.75 & 3.50 & 105.25 \\
Singapore & 91.38 & 3.00 & 94.38 \\
Sri Lanka & 13.14 & 22.41 & 35.54 \\
Thailand & 75.00 & - & 75.00 \\
Republic of Vietnam & - & 11.30 & 11.30 \\
Western Samoa & - & 5.33 & 5.33 \\
\hline Total & $753.01^{1}$ & 201.55 & $954.55^{1}$ \\
\hline
\end{tabular}

1 Excludes $\$ 0.4$ million approved in 1968 and \$ 0.5 approved in 1970 incorporated in new loans in 1970 and 1971, respectively.

Source: Asian Development Bank Report, 1972, p. 42.

Annex A of the Agreement divides the subscribers into two categories: regional and non-regional members. Subscriptions are allotted to regional members in accordance with a scale derived from gross domestic product, adjusted for population, total exports, and total tax revenues. The subscriptions of non-regional members depend on what they are willing to offer above the prescribed minimum of $\$ 5$ million. ${ }^{42}$ The only other stipulation laid down in the Agreement besides this was that the capital stock held by regional members should not be less than $60 \%$ of the total. 
The Articles of Agreement provide for an authorised capital of the Bank of $\$ 1000$ million of which $\$ 500$ million was to be paid-in and $\$ 500$ million was callable if required. At the inaugural meeting, the Board of Governors authorised an increase in the capital stock to $\$ 1,100$ million. At the time of the meeting, the capital subscription amounted to $\$ 970$ million. The paid-in portion of the subscriptions was to be paid in five equal installments. ${ }^{45}$ One half of the paid-in capital was payable in gold or convertible currency, the other half in the currency of the member. ${ }^{46}$ This provision has the effect of doubling the subscriptions (paid-in portion) of those members who have convertible currencies, i.e., the developed countries, in relation to the subscription of the developing countries. This in turn helps to strengthen the position of member countries like the United States, with a convertible currency, within the Bank.

The day-to-day supervision of the general operations of the Bank rests with the Board of Directors. The Board consists of ten Directors, seven to represent the Asian regional countries elected by the governors representing the regional members and three representing the non-regional countries to be elected by the governors representing the non-regional members. The size of the subscriptions of the United States (a non-regional member) and of Japan (a regional member) enables them to elect their own directors to the Board even though the voting procedure does provide some safeguards to ensure a relatively even distribution of voting power among the members of the ADB. To be elected, a director representing the regional countries requires only $10 \%$ of the votes of such countries. In the case of the non-regional countries, however, a director, in order to be elected had to receive at least $25 \%$ of the total votes of non-regional members. Such a procedure was meant to ensure that no director could be elected outright by a single non-regional member. While this particular safeguard seems quite effective for the bulk of the non-regionals, it was not very effective with regard to the United States, since that country already had a high percentage of votes $(17.1 \%)$ allotted to it, and required only a further $7.9 \%$ to assure itself of a directorship.

Likewise, among the regional members, Japan, controlling $17.1 \%$ of the votes, is able to guarantee the election of a Japanese director. Another reason for this disparity in the voting power of the members is the division of the member countries into regional and non-regional members, which results in the directors with the largest number of votes, representing developed countries exclusively! (see Table 2). Hence, the influence of the two most powerful directors in 1967 exceeded by a considerable margin the voting power of the weakest, that the two most powerful directors with $34 \%$ of the votes, represented developed countries exclusively, and that the three weakest directors represented developing countries exclusively. These figures, are therefore indicative of the relative degrees of influence of the member countries, especially the United States and Japan. 
Table 2: Share and Voting Power of Members of the Asian Development Bank 1967-1972

Member Country $\%$ of Total Votes 1967

1972

Developed Countries:

U.S.A.

Japan

17.12

20.24

TOTAL: U.S.A. \& Japan

34.24

28.66

Other non-regional:

Austria

1.04

1.03

Belgium

1.04

0.74

Canada

2.69

3.00

Denmark

1.04

1.03

Finland

1.04

0.74

France

-

1.53

FRG

3.34

1.88

Italy

2.27

1.34

Netherlands

1.53

0.97

Norway

1.04

0.74

Sweden

1.04

0.74

Switzerland

1.04

0.74

U.K.

3.10

3.30

Total: Other Non-Regional

20.30

17.98

Other Regional:

Australia

7.64

8.91

New Zealand

2.48

2.76

Total: Other Regional

10.12

11.67

TOTAL: DEVELOPED COUNTRIES

64.66

58.31

Developing Countries

South Asia:

India

8.30

9.70

Pakistan

3.26

3.69

Ceylon (Sri Lanka)

1.33

1.38

Nepal

0.80

0.60

Afganistan

1.02

1.01

Total: South Asia

14.71

16.38 


\begin{tabular}{lrr}
\hline Member Country & \multicolumn{2}{c}{ \% of Total Votes } \\
\hline Southeasi Asia: & 1967 & $\mathbf{1 9 7 2}$ \\
\hline Indonesia & 2.69 & 3.00 \\
Cambodia & 0.91 & 0.68 \\
Laos & 0.66 & 0.58 \\
Malaysia & 2.27 & 2.51 \\
Singapore & 1.04 & 1.03 \\
Thailand & 2.27 & 2.51 \\
Rep. of Vietnam & 1.61 & 1.72 \\
Phillipines & 3.51 & 3.99 \\
Total: Southeast Asia & 14.96 & $\mathbf{1 6 . 0 2}$ \\
Far East: & & \\
Rep. of China & 1.94 & 2.12 \\
Rep. of Korea & 3.10 & 3.50 \\
Total: Far East & $\mathbf{5 . 0 4}$ & $\mathbf{5 . 6 2}$ \\
Other: & & \\
\hline Western Samoa & 0.63 & $\mathbf{0 . 5 4}$ \\
TOTAL: DEVELOPING COUNTRIES & 35.34 & $\mathbf{3 8 . 6 5}$ \\
\hline
\end{tabular}

Source: Compiled from Asian Development Bank, Annual Report for 1968 and 1972, Appendix I-VII and $\mathrm{I}-\mathrm{V}$ respectively.

Furthermore, the overall impression one gets by examining the speeches of the governors at the annual meetings of the Bank is that the directors most active in policy formulation are those with the largest voting power. ${ }^{50}$ The smaller developing countries, like Cambodia and Ceylon, had anticipated such a development, and they therefore sought concessions, such as an increase in the number of directors to allow them stronger participation in the administration of the Bank. Mr. N. Wimalasena, Governor for Ceylon, in his inaugural speech emphasised this point and observed:

While. .. in drafting the Charter of the Bank an effort was made to give the smaller countries more recognition, it does not seem to have adequately provided a means whereby the smaller countries could participate in the active direction of the Bank's affairs and we hope that steps will be taken to remedy this situation early.

Accordingly, the Agreement provided that after two years the size and composition of the Board of Directors would be reviewed by the Board of Governors. No change was, however, made in the composition of the Board when it came up for review. In any case, a change in the number of Directors would not affect the number of votes cast by the United States or other countries, since voting strength is related to the size of the subscription and not to directorship. 
Thus, each member has one vote for each share he holds. Twenty percent of the votes are allocated as basic votes at a uniform rate of 778 votes per country; the balance is distributed in proportion to each country's subscription. Originally Eugene Black representing the United States, and Takeshi Watanabe on behalf of Japan, fought for $95 \%$ of voting strength to be based on contributions. They reluctantly accepted $80 \%$ of the votes to be based on donations of capital.

Since the balance-of-power within the Bank is overwhelmingly in favour of the developed countries (a ratio of almost 2 to 1), lack of absolute control was not a high price for the United States to pay. It was unlikely that any important decision could be taken against American interests. Important questions required a two-thirds majority so that Japan and any other member could at least theoretically block any major decision. To ensure or block the passage of any proposal by the two-thirds or three-fourths majority required by the charter, they had only to pressure such heavily dependent nations as Taiwan, South Korea, Laos, Thailand, South Vietnam, West Samoa and the Philippines. As Black testified: "the majority of the votes are from the capital exporting countries, which is very important. In other words, the borrowers can't run the Bank."

In addition, it must be borne in mind that one of the Asian members, Japan, is a developed country. As has been pointed out by some in Japan's foreign policy its status as a developed country is emphasised at least as strongly as its adherence to Asia. When the two orientations are in conflict, it is Japan the developed country which tends to dominate. Within the context of the Bank the important point is not that Japan is a regional member, but that it is one of the two principle subscribers with an economic perspective similar to that of the United States.

Thus, the real division within the Bank was between the developed and developing countries, and it was a division in which the developed countries, with nearly twothirds of the voting power, were overwhelmingly the dominant partners. One should perhaps add in this connection that this division was on occasions misleading. The position of the United States and Japan with clear cut objectives was sometimes distinct from that of the other developed countries, for which the Bank was only of marginal interest, and which can therefore take a more flexible approach. Some of these countries became members as a result of American pressure, which was motivated by the desire of the United States to acquire partners in its Asian commitments. Once in, they were bound to give thought to their role. Canada, for instance consistently took a stand which was markedly different from that of the United States. At the first annual meeting of the Board of Governors, for example, the Canadian alternate governor stated his government's view regarding tying contributions to the Special Funds of the Bank. It was a viewpoint that was rather different from that of the United States and Japan:

Our assistance to a Special Fund is intended to be as free as possible from restrictions. Although our contributions will be tied to purchases of Canadian good and services, this provision will apply only to the first round of disbursements. 
He went on to point out that the use of contributions to the Special Funds should be governed not by the general objectives and priorities of the individual members contributing such special funds but by those of the Bank. As a way out of the problem of tied funds, the Canadian Governor suggested that while the contributions could remain tied, they should be "opened to the fullest extent possible to international competitive bidding." This would enable, he argued, the developing recipient nations to procure the required goods and services at the most favourable price. However, nothing was done in order to implement this suggestion.

A further point of note, related to American influence within the Bank, is that the origins of its involvement - problems of political instability in Southeast Asia, increasing problems in Vietnam, it's strong investment and trade interests in the region suggested that the Bank would be most active in Southeast Asia. As will be seen a little later, this is precisely the area in which the Bank concentrated its lending activities during the early years of its operations. Given the highly skewed distribution of voting power within the ADB, an orientation of this kind could not spring from the Bank's Asian character. With less than $15 \%$ of the voting power the Southeast Asian countries constituted a very small minority. Thus, the concentration on this region tends to further corroborate the contention that the Asian Bank at its founding was not an Asian institution, but rather a policy instrument for the pursuit of the interests of its largest donors, made possible by the nature of the voting system. It was for this reason that David Kennedy, Secretary of the Treasury in his letter to Gale McGee, Chairman of the Subcommittee on Foreign Operations, U.S. Senate wrote:

Congress has made funds available to these institutions because of their... important contribution... to furthering United States objectives in Southeast Asia. ${ }^{57}$

\section{The ADB's Lending Operations}

Up to this point I have tried to document the extent of American influence (as also Japan's, America's close friend and ally) in shaping the organisation and structure of the Bank, especially the way in which voting power was distributed among its members. Now I want to demonstrate how United States influence within the Bank has manifested itself in one crucial aspect of the Bank's day to day activities, namely its lending operations, the primary rationale for the ADB's activities.

President Watanabe once argued that his Bank should be a bank with "a heart," not simply a "money lending machine." Paradoxically, this is precisely what the Bank seemed to have become. A partial explanation for this would seem to lie in, as Watanabe has often stated, the need to follow sound banking principles. In practice this meant establishing a high credit standing and proving the worthiness of the institution. However, since the Bank at the same time professes to pay special attention to the needs of the smaller, poorer regional countries, this explanation does not seem fully satisfactory. An alternative and more plausible one, and one that goes against the dominant narrative, is to be found in the fact that the Bank, under pressure from the capital exporting 
countries like the United States and Japan, wanted to emphasise its role as a "bank" more than that of a regional financial institution, whose primary tasks are to promote the economic and social well being of its Asian members.

This orientation is only to be expected given the considerations underlying ADB loans. A review of the statutes reveals three primary considerations which can be summarised as follows: 1) Priority is to be given to countries where certain conditions making for viable development exist and with populations possessed of the will to work; 2) Aid will be restricted to countries possessed of sufficiently ample means to ensure repayment; 3) Interest rates will be adjusted, so far as this proves feasible, with due attention being paid to the nature of the loan granted, but the Bank will be required to ensure that it receives a reasonable return. ${ }^{59}$ These principles, from the ADB's point of view, were basic to sound banking and vigorously supported by the US. In the words of United States Treasury Secretary Fowler the Bank was expected to "concentrate its energies and skills first and foremost on becoming a banking institution . . . [with] prudent management of funds, high standards of loan appraisals ... [and] policies that permit accumulation.... ${ }^{60}$ A comparison of the guidelines laid down by the Bank and those laid down by Secretary Fowler shows that the American vision prevailed.

Between $1968^{61}$ and 1972 (Table 3), 77\% (117 loans totaling $\$ 753,005,000$ million) of all ADB loans were hard loans made out of its ordinary resources. The terms of these loans ranged from ten to twenty-five years at a rate of $6.9 \%$ (which was increased in mid 1970 to $7.5 \%$ ). On these terms the Bank's loans could hardly be called aid. They are scarcely distinguishable from commercial bank loans. Not surprisingly, the ADB's first loan went to the Industrial Finance Corporation of Thailand, an institution that could easily have gotten the money elsewhere.

Table 3: ADB Loan Approvals 1968 -1972 (million US \$)

\begin{tabular}{|c|c|c|c|c|c|c|}
\hline \multirow[b]{2}{*}{ Year } & \multicolumn{2}{|c|}{$\begin{array}{l}\text { Loans From Ordinary } \\
\text { Capital Resources }\end{array}$} & \multicolumn{2}{|c|}{$\begin{array}{c}\text { Loans From Special } \\
\text { Resources }\end{array}$} & \multicolumn{2}{|c|}{ Total Loans } \\
\hline & Amount & No. & Amount & No. & Amount & No. \\
\hline 1968 & $41,600,000$ & 7 & - & - & $41,600,000$ & 7 \\
\hline 1969 & $76,095,000$ & 14 & $22,005,000$ & 6 & $98,100,000$ & 20 \\
\hline 1970 & $211,940,000$ & 22 & $33,693,000$ & 10 & $245,633,000$ & 32 \\
\hline 1971 & $202,520,000$ & 16 & $51,510,000$ & 12 & $254,030,000$ & 28 \\
\hline 1972 & $221,750,000$ & 16 & $94,340,000$ & 16 & $316,090,000$ & 32 \\
\hline TOTAL & $753,005,000$ & $73^{1}$ & $201,548,000$ & 44 & $954,553,000^{1}$ & 117 \\
\hline
\end{tabular}

Source: ADB Annual Reports 1968-1972. 'Excludes \$0.5 million appioved in 1968 and $\$ 0.5$ million approved in 1970 incorporated in new loans in 1970 and 1971 respectively. 
Given the interest rates which have applied to its ordinary funds, ADB loans only added to the debt burden of the poor nations of the area, already staggering under service payments in view of an existing foreign debt of about $\$ 1.2$ billion per year. ${ }^{\text {(2) }}$ Only 23\% (44 loans totaling $\$ 20,548,000$ ) of ADB loans advanced between 1968 and 1972 were "soft" (low interest) ones. Although between 1971 and 1972 the amount of the soft loans approved by the Bank increased by $54.6 \%$ ( $\$ 42,830,000$ million), it was still far less than the amount of ordinary loans approved by the Bank. These loans were made from the Bank's "Special Funds," donated by individual countries with strings attached to them. These funds are not, however, part of the Ordinary Funds of the Bank. The comparatively larger amount of ordinary loans made by the Bank, based on the capability of its Asian regional members to pay higher rates of interest, is, therefore, reflective of the viewpoint of the developed-countries and the relatively more developed Asian regional countries, that the Bank must follow sound banking principles. The support of countries like the Republic of Korea, Republic of China, Thailand and so on for the Bank's lending policy was only to be expected since they naturally felt that they would be the prime beneficiaries of such a policy.

An operative philosophy of this kind, hence had its spin-offs for the United States in the form of furthering its political, security and economic interests in Southeast Asia. Of all the regional developing countries of Southeast Asia, only relatively more developed countries like Thailand, Republic of Korea, Philippines, Republic of China and so on had the capacity to draw up sound loan proposals and absorb the high interest rates on Ordinary loans. Since the bulk of the ADB loans have been made from its ordinary resources, it is these countries which tended to benefit most from the ADB's lending activities. It should at the same time be borne in mind, that these are the very countries in which the United States had deep and abiding interests. Hence, it can be argued that by concentrating its ordinary loan operations in these countries, the Bank not only helped to reduce American aid commitments to these countries, but also in the long run, by promoting economic growth and the concomitant stability that would result from it, served (from the point of view of United States thinking at least) to make these countries less vulnerable to communist influence, thus fulfilling a major goal of United States Cold War foreign policy. Simultaneously, the enhanced economic prosperity of these countries makes them more attractive for the American investor in terms of trade and investment.

The "soft loans" of the Bank also tend to serve a similar purpose. These loans have generally gone to a handful of relatively less developed countries of Asia like Indonesia. As the loans from the soft funds are tied loans, and since the United States happens to be one of two major contributors, those countries which received loans from the United States share of the contribution to the Special Funds will of necessity be tied to it economically and politically. ${ }^{63}$ Indonesia which monopolised the soft loans of the Bank was a good case in point. Since the overthrow of President Sukarno in October 1965, by means of a military coup, it was dependent on direct American aid and aid assistance channeled through American dominated financial institutions making it politically and economically dependent on the United States. 
An analysis of the distribution of ADB loans by country helps to illustrate the extent to which the ADB served the interests of the United States. Table 3 shows the distribution of ADB Ordinary and Special Funds loans by country up to the end of 1972. Four nations, Taiwan (\$196.8 million), South Korea (\$100.4 million), Philipines (\$101.5 million), and Thailand (\$74.2 million) together received $62.8 \%$ ( $\$ 473.4$ million) of all ADB loans made out of its ordinary resources. Out of the $\$ 201.5$ million soft loans made by the Bank, Indonesia alone garnered $\$ 69.6$ million (34.5\%), Philippines ( $\$ 3.5$ million), Taiwan ( $\$ 3.7$ million) and South Vietnam ( $\$ 11.3$ million). Together these four nations accounted for $43.7 \%$ of the Bank's soft loans. Ten other countries - Afghanistan, Cambodia, Laos, Malaysia, Nepal, Pakistan, Papua New Guinea, Singapore, Sri Lanka and Western Samoa - have together received only $\$ 113.4$ million or $57.3 \%$ of all soft loans.

It should be clear from the way the Ordinary and Soft loans were distributed that the bulk of ADB loans between 1968 and 1972 went to those countries which were closely aligned to the United States, both politically and economically. What is noteworthy about all these countries is their dependence on the United States, which made them pliable and cooperative allies, a fact that assumes great importance with respect to the pattern of distribution of ADB loans. Viewed from this perspective it does not seem to be sheer coincidence, that Indonesia, Republic of Korea, Philippines, Thailand, and Republic of China, countries which together accounted for $72.2 \%$ ( $\$ 1183$ million) of all American aid to South and Southeast Asia in $1971^{64}$ (excluding India ) also received 90.6\% (\$230.1 million) of ADB loans from its Ordinary and Special Funds during the same year. A significant point that emerges out of the foregoing discussion is that the $\mathrm{ADB}$ has been most active in Southeast Asia, rather than in "Asia," an understandable fact considering that it happens to be the primary area of American interest in Asia. As Black emphasised during his testimony before the Senate Foreign Relations Committee in 1967: ". . . as far as the United States is concerned our interest is that this money [contribution to the Special Funds] be used in ... Southeast Asia," an area of "primary interest" to the United States. For this reason, the Special Report of September 1967 of the National Advisory Council on International Monetary and Financial Policies on Special Funds of the ADB states that the United States, at the time it initially agreed to provide the funds "can stipulate the purpose for which the funds could be used and the basis on which they would be made available." A special geographic emphasis seems to have been an implicit stipulation which was attached to the United States contribution to the Special Funds of the ADB.

The ADB's president Mr. Takeshi Watanabe once claimed that the Bank is not guided by political considerations, or open to pressure from any country, when it examines the merits of a project proposal. In fact, this has not always been the case. For example, the ADB did not make any loans to Cambodia while Prince Norodom Sihanouk was in power, primarily because during the later years of his rule he had become an outspoken critic of United States policy in Southeast Asia. ${ }^{69}$ Its single loan to Cambodia was approved two weeks after the coup which overthrew him, and established a regime under Lon Nol, favorably oriented towards the United States and the free enter- 
prise system. ${ }^{70}$ The new, acceptable attitude of Cambodia was apparent in the statement made by Mr. Mau Say, the Alternate Governor for Cambodia at the third annual meeting of the Board of Governors, held in Seoul, in April 1970:

...our nation is more than ever determined to follow the path leading to nation building by promoting private initiative and by practicing an open door policy.... Furthermore, new and liberal laws grant numerous advantages and facilities to foreign investors. They offer many opportunities for the employment of available capital which will not fail to find security and profitability on Cambodian territory.

\section{Conclusion}

The conclusions to be drawn from the preceding discussion can be summed up very briefly. The Asian Development Bank is certainly a bank and on that basis it is not to be criticised for seeking a high standard in being what it is. A large part of the reason for this orientation is to be found in the priorities of its major donors, the first of which was the establishment of a sound banking institution. Consequently, its role as a Bank has been emphasised more than its role as a "catalyst" to promote regional economic cooperation among its members.

Again, because of the influence of its major financial backers, - the United States and Japan, the geographical focus of the Bank's lending activities has been predominantly Southeast Asia, with particular attention having been given to five major Asian allies of the United States: Indonesia, Philippines, Republic of Korea, Republic of Taiwan and Thailand.

Although the Bank was supposed to be an independent "Asian" institution, in it early years (and even to a large extent today) it was neither independent nor "Asian." First, except for Japan, the most influential members of the Bank are not Asians. Second, power within the Bank rests primarily with the United States and Japan along with the other developed member nations. For all practical purposes, the Bank became an agency for the transmission of multilateral aid and western technology to countries selected largely by its developed members. Finally, loans made by the Bank went predominantly to those countries in which the United States had significant economic and political interests. In short, one of the major reasons for American interest in creating the Bank was that it was well-suited to further it's economic and political interests in Southeast Asia.

\section{Notes}

1. For a review of this perspective, though not specifically in the context of the ADB see Nitish Dutt, "The United States and the Asian Development Bank," Journal of Contemporary Asia, 1997, 27: 71-84.

2. See J. R. Strang, "State Power in a Multilateral Context: Voting Strength in the Asian Development Bank" International Interactions 1999, Vol 25:3, pp. 265-286; M. T. Berger, "APEC and Its Enemies: The Failure of the New Regionalism in the Asia Pacific, Third World Quarterly, Vol. 20:4, pp. 10131030; M. Wan, "Japan and the Asian Development Bank, Pacific Affairs 1996, Vol. 68:4, pp. 509-21. Dutt, 1997, n. 1. For a similar examination of three role of the IMF see Theresa Hayter's classic inside study of the IMF, Aid as Imperialism (London: Penguin, 1974). 
3. Far Eastern Economic Review, April 14, 1966, p. 59. Henceforth cited as FEER.

4. Asian Development Bank, Annual Report for 1967 (Manila: 1967) p. 4. Hereafter cited as ADB Annual Report.

5. ECAFE Annual Report for $1963 / 64$ (E/CN.11/662/Rev.1) p. 20. Henceforth cited as ECAFE Report.

6. While testifying before the House Committee on Banking and Currency Mr. Black stated: " $\ldots$ he (Mr. Watanabe) was my pick for the presidency of the Bank because I think it is very important who heads an institution." Congress, House Committee on Banking and Currency, Asian Development Bank Act Amendments of 1968, p. 71 . Hereafter cited as $A D B$ Act .

7. See Henry S. Bloch, "Regional Development Financing," International Onganisation 22 (Winter 1968), p. 191.

8. FEER, p. 59.

9. Resolution 54.

10. The Report is reproduced along with a comparative analysis of the African and Inter-American banks, in Regional Economic Cooperation in Asia and the Far-East: The Asian Development Bank and Trade Liberalization, E/CN. 11/707 (NY: United Nations, 1965). Henceforth cited as Report.

11. Eugene R. Black, Alternative in Southeast Asia (London: 1969) p. 100. Cited as Black.

12. See for instance the statement of the Governor for Cambodia, Mr. Son Sann, Inaugural Meeting, Summary of Proceedings, pp. 2-25.

13. Loans from the Ordinary Funds were supposed to be made at conventional rates of interest, without any strings attached to them.

14. U.S. Senate, Committee on Foreign Relations, Asian Development Act, Hearing on H.R. 12563, 89th Cong., 2nd sess., February 16, 1966, p. 7. Henceforth cited as $A D B$ Act Hearing. See also Asian Development Bank Special Funds. Hearing on 2479, 90 th Cong., Ist sess., October 3, 1967, p. 3. Hereafter cited as $A D B$ Special Funds, Hearing.

15. For the text of the Charter see $A D B$ Act, Hearing, Appendix 2, pp. 75-104.

16. ECAFE Report 1964/65, pp. 157-161.

17. Ibid., p. 143.

18. Resolution $62(\mathrm{XXI})$.

19. The Japanese representative was again Mr. Takeshi Watanabe.

20. See Nitish Dutt, "The United States and the Asian Development Bank." op. cit., n2.

21. Black, p. 97.

22. White, Regional Development Banks, p. 47.

23. Ibid., p. 47.

24. ADB Special Funds, Hearing, p. 22.

25. For an interesting account of how Manila came to be selected as the Bank's headquarters see, Ibid., pp. 48-49.

26. ADB Annual Report for 1967, p. 4.

27. The countries were: Afghanistan, Australia, Austria, Belgium, Cambodia, Canada, Ceylon, Republic of China, Denmark, Finland, Federal Republic of Germany, India, Italy, Japan, Republic of Korea, Laos, Malaysia, Nepal, Netherlands, New Zealand, Norway, Pakistan, Philippines, Republic of Vietnam, Singapore, Sweden, Thailand, United Kingdom, U.S.A., and Western Samoa. In addition Indonesia was admitted at the inaugural meeting by an accelerated procedure after the overthrow of Sukarno.

28. Message from President Johnson transmitting Agreement Establishing the Asian Development Bank, 89th Cong., 2nd sess., House Document No. 361, reproduced in ADB Act, p. 71.

29. This, at least, is the general conclusion of such statistical analyses as have been undertaken by the Organisation for Economic Cooperation and Development, and is confirmed by more detailed surveys which exist for U.S. overseas-investment. See for instance U.S. Congress, House, Committee on Foreign Affairs, Report of Subcommittee on Foreign Economic Policy, The Involvement of U.S. Private Enterprise in Developing Countries. H..R. No. 1271, Washington, D.C.: 1968.

30. Inaugural Meeting, Summary Proceedings, 1966, Appendix F.

31. Article I, Agreement Establishing the Asian Development Bank, hereafter cited as Agreement, reproduced in $A D B$ Act Hearing, p. 76.

32. Article 2, Ibid. 
33. Special Report of the National Advisory Council on International Monetary and Financial Policies on Special Funds of the Asian Development Bank, September 1967, henceforth cited as Special Report. The report is reproduced in ADB Special Funds, Hearing, Appendix, p. 46.

34. Statement of Eugene Black before House Banking and Currency Committee, Subcommittee on International Finance, Asian Development Bank Act Amendments 1968, p. 47.

35. Ibid., Article 3.

36. ADB Special Funds, Hearing, p. 15.

37. White, Regional Development Banks, p. 15.

38. Bloch, "Regional Development Financing," p. 190.

39. See Indonesia Leaves the United Nations, Indonesian Policy Series No. 22, Djakarta: 1966. See also Nitish Dutt, "Indonesia - India Relations 1955-1967," Asian Studies 10, (August 1972) pp. 196-220.

40. Inaugural Meeting, Summary of Proceedings 1966, p. 25.

41. ADB Annual Report, p. 6.

42. Agreement, Annex A.

43. Ibid., Article 6(2).

44. By December 1972 , the total subscriptions had increased to $\$ 2,985,714,000$.

45. Article 4., Agreement, reproduced in ADB Act Hearing, p. 90.

46. Article 6(2), Ibid.

47. Article 30(1), Ibid.

48. For further details about the complex process by which directors are elected see Agreement, Annex B.

49. ADB Annual Report for 1969, Appendix 1-V and 7. Percentages do not add up to 100 as Switzerland was at that time unrepresented.

50. See for instance the Summary Proceedings of the annual meeting of the Board of Governors, 1967-72.

51. Inaugural Meetings, Summary Proceedings; 1966, Ibid., p. 28. The Governor for Cambodia expressed a similar point of view at the meeting: "Regarding the regional countries with small voting power, we consider that it is necessary to favour them by allowing a stronger participation in the administration of the Bank; for this reason it would be useful to increase as soon as possible the numbers of Directors elected by regional members." p. 25.

52. FEER, April 14, 1966, p. 59.

53. House Committee on Banking and Currency, Subcommittee on International Finance, Asian Development Bank Act Amendments, 1968, Hearing 90th Cong., 2nd sess., February 27, 1968, p. 80.

54. For a good discussion of this point see J. White, Japan's Foreign Policy," in Venture 17 (Dec. 1965).

55. ADB's first annual meeting of the Board of Governors, Manila: 4-6 April 1968, Summary of Proceedings, p. 30. Emphasis added.

56. Ibid., pp. 30-31.

57. Senate, Committee Appropriations, Foreign Assistance and Related Progrums Appropriations for Fiscal Year 1971, Hearings, 91st Cong., 2nd sess., August 24, 1970, p. 17.

58. Watanabe's speech at the inaugural meeting, 24 November 1966, Summary of Proceedings, p. 16.

59. Ibid., pp. 23-24.

60. Ibid., p. 63.

61. No loans were made prior to 1968.

62. ADB Annual Report 1973, p 9.

63. India has been excluded from the computation because it is a donor nation.

64. Figures for 1971 have been used since comparable figures of American aid and ADB loans to Asian members were not available for all countries for years other than 1971.

65. ADB Special Funds, Hearing, 1967, p. 23.

66. Special Report, Ibid., p. 46.

67. Takeshi Watanabe, Paths to Progress: A Collection of Speeches, (Manila: ADB, 1971) p. 65.

68. FEER.

69. ADB Annual Report, 1967, p. 94.

70. Speech at the third annual meeting of the Board of Governors, Seoul, 9-11 April, 71. Summary of Proceedings 1970, p. 32. 